\title{
COMMENTS
}

\section{Exclusion of Contingent Attorneys' Fees from Gross Income}

\author{
Stephen D. Feldman $\dagger$
}

A plaintiff and attorney who enter into a contingent fee contract have a unique relationship. The plaintiff has hired the attorney to maximize his return on a potential legal claim. He could proceed pro se, but he believes that the attorney's experience will yield a more favorable judgment despite the fact that his attorney receives, pursuant to their contract, a portion of the judgment or settlement. In reality, the plaintiff is never able to access the attorney's portion of the recovery. Nonetheless, under current tax law, a plaintiff in certain jurisdictions must pay federal income taxes on the attorney's share of the judgment or settlement.' Because the attorney has a strong contractual right tantamount to an ownership interest in the settlement or judgment, ${ }^{2}$ and, alternatively, because the plaintiff has no effective means to gain dominion over the entire recovery, this Comment argues that courts should permit plaintiffs to exclude contingent attorneys' fees from their gross income for tax purposes.

Currently, courts disagree on whether to permit exclusion. Some courts have disallowed exclusion because of the anticipatory assignment of income doctrine. According to this doctrine, a taxpayer cannot avoid taxation by assigning his income to another. ${ }^{3}$ The assignment of income doctrine, however, evolved from a set of cases that can

$\dagger$ B.S.B.A. 1999, Washington University; J.D. Candidate 2002, The University of Chicago.

1 An individual can, in certain cases, exclude compensatory damages and deduct attorneys' fees. In many cases, however, an individual can do neither. See Part I.A.

2 See, for example, Alderman v Pan Am World Airways, 169 F3d 99, 102-03 (2d Cir 1999) (stating that courts should rarely interfere with contingent fee contracts because it is "the freely negotiated expression both of a [client's] willingness to pay more than a particular hourly rate to secure effective representation, and of an attorney's willingness to take the case despite the risk of nonpayment"), quoting Wells v Sullivan, 907 F2d 367, 371 (2d Cir 1990). See Part III.A.1 for a complete discussion.

3 See Lucas v Earl, 281 US 111,114-15 (1930) (stating that a taxpayer cannot avoid paying income tax "by contracts however skilfully [sic] devised to prevent the salary when paid from vesting even for a second in the man who earned it"). 
be distinguished from the contingent fee arrangement, and this Comment proposes that exclusion of attorneys' fees does not violate that doctrine.

Although some courts currently permit exclusion, they rely on inconsistent rationales. The Fifth and Sixth Circuits have permitted exclusion on the ground that relevant state law creates a charging attorney's lien giving the attorney and the plaintiff the same power over income resulting from a favorable judgment. If the plaintiff will never see the attorney's portion of the judgment, these circuits argue, then the plaintiff should not be taxed on it because it never belonged to him. On the other hand, the Fifth Circuit has also permitted exclusion when state property law does not grant the plaintiff and the attorney the same power over judgment proceeds. Against this backdrop of uncertainty in the Fifth Circuit and other courts, this Comment argues that state law should not affect whether plaintiffs can exclude contingent fees.

Although courts currently base their exclusion decisions on either the assignment of income doctrine or state law, neither analysis was designed as a method of deciding the exclusion question. The result is that neither analysis is instructive or predictive of outcomes in exclusion cases; a court might use either analysis to rule for or against exclusion. In contrast, a rule requiring exclusion based on the attorney's virtual ownership interest in the claim as created by the contingent fee arrangement itself, not by state law, would provide consistency in analysis and, therefore, in outcomes.

The issue of excludability is important because of the enormous sums of money involved. The cases in which taxpayers have sought to exclude contingent fees have involved exclusions of almost two million dollars. ${ }^{4}$ For most individuals, two million dollars is quite significant.

4 See, for example, Estate of Clarks v United States, 202 F3d 854, 855 (6th Cir 2000) (stating the question in the case as whether the plaintiff must include in taxable income over $\$ 1.9$ million paid directly by the defendant to the lawyer as interest on a contingent fee).

5 Unfortunately, fee shifting cannot solve this problem. The Supreme Court has upheld the enforcement of contingent fee contracts even when fee shifting occurred (generally, fee shifting means that a court, authorized by statute, orders a losing defendant to pay the victorious plaintiff reasonable attorneys' fees, calculated on an hourly basis). See Venegas v Mitchell, 495 US 82, 89-90 (1990) (upholding a contingent fee arrangement even though the attorney received a higher payment under it than the payment due him under the fee-shifting statute). Thus, contingent fee contracts can exist alongside statutory fee shifting, so the possibility of fee shifting does not moot the issue of exclusion of contingent fees. Besides, even if fee shifting and contingent fee arrangements were mutually exclusive, it is highly unlikely that attorneys and their clients would totally abandon contingent fee contracts and rely exclusively on statutory fee shifting. Most lawyers probably would hesitate to take fee-shifting cases if the hourly rate was the only form of remuneration, and moreover awarded only if successful. In addition, the majority of the case law concerning the exclusion of contingent fees involves cases not subject to a statute that authorizes fee shifting. See, for example, Clarks, 202 F3d at 854 (involving exclusion in a personal 
Part I of this Comment explains the tax law relevant to the exclusion of contingent attorneys' fees. Part II introduces the germane case law. Part III analyzes the tensions presented by the divergent outcomes courts have reached and the inconsistent legal reasoning they have used. Part III.A argues that the assignment of income doctrine does not mandate that attorneys' fees must be included in gross income. Part III.B argues that state property law should not be a factor in deciding whether the attorney has a proprietary interest in the legal claim such that exclusion is appropriate. Finally, Part IV proposes that courts should allow taxpayers to exclude attorneys' fees because a taxpayer should not be taxed on a portion of his legal claim in which his attorney has effectively secured a proprietary interest.

\section{RELEVANT TAX LAW}

This section introduces two tax law concepts helpful to understanding why the exclusion of contingent attorneys' fees from federal income taxation is a significant issue. Part I.A provides a brief explanation of why taxpayers cannot deduct all attorneys' fees or exclude all punitive damages from income under the Internal Revenue Code and the consequences of the Code's deduction limitations. Part I.B explains the assignment of income doctrine, a common law doctrine that many courts use to preclude exclusion. The doctrine's history shows that courts misapply it in the contingent fee scenario.

\section{A. Limits on Deduction of Attorneys' Fees and Exclusion of Punitive Damages}

The Code limits plaintiffs' ability to deduct attorneys' fee awards and their ability to exclude punitive damage awards. First, an individual can deduct attorneys' fees only when the fees are ordinary and necessary trade or business expenses ${ }^{6}$ or when they are ordinary and necessary expenses that arose in connection with the individual's profit-seeking activities.' Furthermore, attorneys' fees that are deductible because they arose in connection with profit-seeking activities are classified as miscellaneous itemized deductions. ${ }^{8}$ A miscella-

injury claim). See also all cases cited in Part II.

626 USC \& 162(a) (1994 \& Supp 1998) ("There shall be allowed as a deduction all the ordinary and necessary expenses paid or incurred during the taxable year in carrying on any trade or business.").

726 USC $\$ 212$ (1994). The origin of the claim test determines whether the expense was business or personal, and, hence, whether it was deductible. See United States $v$ Gilmore, 372 US $39,48-49$ (1963) (holding that attorneys' fees are deductible as business expenses if they arise in connection with the taxpayer's profit-seeking activities).

826 USC \& 67(b) (1994 \& Supp 1998). The Code enumerates in $\$ 67$ (b) certain items that may be fully deducted; attorneys' fees are not explicitly enumerated, and anything that is not 
neous itemized deduction is permitted only to the extent that the aggregate of such deductions exceeds two percent of adjusted gross income. Additionally, the taxpayer cannot deduct miscellaneous itemized deductions if he is subject to the Alternative Minimum Tax ("AMT"). ${ }^{10}$ A taxpayer must pay the AMT whenever his liability under the AMT is greater than his liability under the regular tax." Consider the plaintiff in Alexander $v I R S^{12}$ who could not deduct any of his attorneys' fees: his tax liability turned a $\$ 5,000$ pre-tax gain into a $\$ 48,900$ after-tax loss. ${ }^{13}$ These Code provisions explain why individuals attempt to exclude, rather than deduct, attorneys' fees.

The Code limits exclusion, however. Most damage awards include compensatory damages, meant to recompense the plaintiff for his actual loss, ${ }^{14}$ and punitive damages, imposed upon the defendant for the manner in which he inflicted the plaintiff's injuries. ${ }^{15}$ Under the Code, an individual can exclude only compensatory damages-specifically, damages that are received on account of personal injuries or sickness. ${ }^{16}$ In contrast, the Code does not permit a taxpayer to exclude punitive damages or interest from taxation. ${ }^{17}$ For this reason, it is noteworthy that compensatory damages can be significantly lower than punitive

enumerated is a miscellaneous itemized deduction. Id.

926 USC \& 67(a) (stating that "the miscellaneous itemized deductions for any taxable year shall be allowed only to the extent that the aggregate of such deductions exceeds 2 percent of adjusted gross income").

1026 USC \& 56(b)(1)(A)(i) (1994) (disallowing miscellaneous itemized deductions to taxpayers subject to the AMT). For a discussion of the mechanics and underpinnings of the AMT, see William D. Andrews, Basic Federal Income Taxation 779-81 (Aspen 5th ed 1999).

1126 USC § 55(a) (1994).

1272 F3d 938 (1st Cir 1995).

13 Id at 940. See also Laura Sager and Stephen Cohen, How the Income Tax Undermines Civil Rights Law, 73 S Cal L Rev 1075, 1078 (2000) (using Alexander to demonstrate the drastic tax burden that can result from AMT deduction limitations). Plaintiffs subject to these deduction limitations often claim that the provisions are unfair. That, however, may not be the case; the AMT represents a decision by Congress to reduce deductions and tax more income at a lower rate. See Andrews, Basic Federal Income Taxation at 779-81 (cited in note 10).

14 Richard A. Epstein, Modern Products Liability Law 172 (Quorum 1980) (distinguishing actual damages from punitive damages).

15 Id.

1626 USC $\$ 104(a)(2)$ (1994). Although courts have debated the definition of "personal injuries or sickness," that inquiry is outside the scope of this Comment. For further discussion, see Commissioner $v$ Schleier, 515 US 323, 336-37 (1995) (discussing two-prong test for applicability of $\S 104(a)(2))$. In general, courts look to the nature of the taxpayer's underlying claim to determine if the taxpayer can exclude the recovered amount. See, for example, Hukkanen-Campbell $v$ Commissioner, $79 \mathrm{Tax} \mathrm{Ct}$ Mem Dec (CCH) 2122, 2124 (2000). The Supreme Court has noted that the term "personal injuries," as defined in $\S 104(a)(2)$, covers nonphysical injuries in addition to physical injuries. United States v Burke, 504 US 229, 235-36 n 6 (1992). The Court has also laid out the requirement that a stronger causal connection than a "but-for" connection between injury and damages is necessary to prove personal injury damages. O'Gilvie v United States, 519 US $79,82-83(1996)$.

17 See $O^{\prime}$ Gilvie, 519 US at 83 (holding that under $\S 104(a)(2)$ punitive damages are not excludable from gross income). 
damages. For example, the Federal Circuit recently upheld a damage award with a punitive to compensatory damages ratio of thirty-eight thousand to one. ${ }^{18}$ The Supreme Court has stated, "[L]ow awards of compensatory damages may properly support a higher ratio than high compensatory awards, if, for example, a particularly egregious act has resulted in only a small amount of economic damages."

Thus, whenever the majority of the damage award consists of punitive damages, the victorious plaintiff must include most of the recovery in taxable income. If the plaintiff and attorney have entered into a contingent fee contract, part of what is nominally the plaintiff's recovery is in reality the attorney's fees. But since the plaintiff must include most of the nominal recovery (all punitive damages) in income, the plaintiff must pay taxes on the attorney's portion of the award, absent some other basis for nontaxation.

The Code does not distinguish between contingent fees and hourly fees in determining deductions; the deduction permitted by $\S 162(a)$ is simply for "ordinary and necessary expenses paid or incurred during the taxable year in carrying on any trade or business," and the deduction permitted by $\S 212$ is for "ordinary and necessary expenses paid or incurred during the taxable year" for nonbusiness income-producing activities, such as investing. ${ }^{21}$ This Comment argues that although the Code does not distinguish between hourly and contingent fees for deductions, and does not permit exclusion of either, the unique nature of the contingent fee scenario justifies exclusion of contingent fees. Although it might be argued that all legal fees should be treated similarly as a matter of equity, hourly fees should not be excluded because a plaintiff who hires an attorney on an hourly basis unquestionably receives as income all proceeds from a judgment or settlement. The contingent fee plaintiff, however, receives only a portion of the proceeds pursuant to contract terms.

18 Tronzo v Biomet, Inc, 236 F3d 1342, 1350 (Fed Cir 2001) (noting that "the constitutionality of a punitive damages award is not simply a matter of numbers or ratios").

$19 B M W$ of North America, Inc v Gore, 517 US 559, 582 (1996) (adding that a higher ratio could also be justified when an injury is hard to detect or the monetary value of non-economic harm is difficult to determine).

2026 USC $\$ 162($ a).

2126 USC $\$ 212$.

22 See Srivastava v Commissioner, 220 F3d 353, 357 (5th Cir 2000) (arguing that as a matter of "tax neutrality," contingent fees should not be excluded because hourly fees cannot be excluded).

23 See Part III.A.1. 


\section{B. The Assignment of Income Doctrine}

The Supreme Court introduced the anticipatory assignment of income doctrine in Lucas $v$ Earl. $^{24}$ In 1901, taxpayer Earl and his wife entered into a contract whereby any income and property that either spouse received during his or her lifetime became the property of both. $^{25}$ In 1920, Mr. Earl reported only half of his income with the rationale that his wife, not he, owed taxes on the other half of his income pursuant to their contract. ${ }^{26} \mathrm{~A}$ unanimous Court decided in favor of the IRS, reasoning that a taxpayer cannot escape paying taxes on all "income derived from salaries, wages, or compensation for personal service" ${ }^{, 27}$ through anticipatory assignments of income, no matter how "skilfully [sic] devised."

While Earl addressed the assignment of income from wages, Corliss $v$ Bowers $^{29}$ and Helvering $v$ Clifford $^{30}$ dealt with the assignment of income from property. The taxpayer in Corliss, who retained the power to revoke a trust, violated the assignment of income doctrine by assigning trust income to a beneficiary and then not including the trust income in his gross income. The taxpayer in Clifford, who held a reversionary interest in a trust, also violated the doctrine by assigning income from the trust and excluding the trust income from his taxable gross income. ${ }^{32}$ According to the Supreme Court: "[T]axation is not so much concerned with the refinements of title as it is with actual command over the property taxed - the actual benefit for which the tax is paid."

The Court expressed the rigidity of the assignment of income doctrine in Helvering $v$ Horst, ${ }^{34}$ in which the taxpayer, Horst, assigned detachable coupon bonds to his son. ${ }^{35}$ Horst lost complete control of

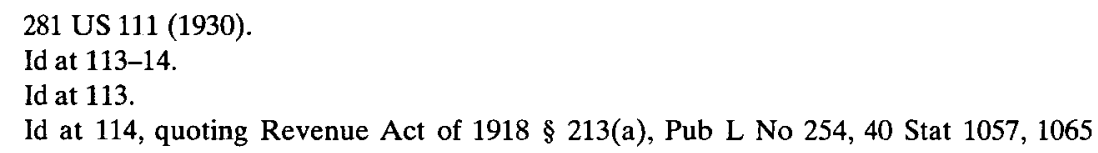

31281 US at $377-78$ (holding that a taxpayer who assigned income to a trust with the power to modify the terms of the trust violated the assignment of income doctrine by excluding income assigned to trust from gross income).

$32 \quad 309$ US at 335-38 (noting that because the taxpayer husband retained control over the income assigned to the family trust, the taxpayer could not exclude the assigned income). The holdings of Corliss and Clifford have been codified in the Internal Revenue Code. See 26 USC $\S \S 673,676(1994)$.

33 Corliss, 281 US at 378.

34311 US $112(1940)$.

35 Id at 114. The owner of a coupon bond has the right to receive interim interest payment on the bond in the amounts and dates specified by the coupons. See id at 115 . The owner of a detachable coupon bond can literally detach the coupon and sell it independently. See Steven A. 
each coupon bond once he made each transfer. ${ }^{36}$ Nonetheless, Horst could not exclude the coupon bond income. ${ }^{37}$ The Court explained its ruling as a mandate of the unbending rule of Earl: when the assignor receives a benefit, he cannot escape taxation by assigning this income to another.

These cases demonstrate two points important to contingent fee taxation. First, according to Corliss and Clifford, control over property results in taxation; a plaintiff with a contingent fee contract, however, has no control of the property taxed. ${ }^{39}$ Second, under Horst, the receipt of certain benefits results in taxation; a plaintiff with a contingent fee contract, however, has received no "benefit" in the same sense as in Horst. $^{40}$

\section{EXCLUSION, THE ASSIGNMENT OF INCOME DOCTRINE, AND ATTORNEY'S LIENS}

This Part examines the two theories courts apply in contingent fee exclusion cases: the assignment of income doctrine and state law.

\section{A. The Assignment of Income Approach}

In Baylin $v$ United States, ${ }^{41}$ the Federal Circuit held that a taxpayer could not exclude contingent fees because the contingent fee contract violated the assignment of income doctrine. ${ }^{42}$ The Federal Circuit found that the plaintiff's legal claim had value before the hiring of an attorney and that the plaintiff assigned some of that value to the attorney in exchange for the attorney's services. ${ }^{43}$ According to the court, the fact that the plaintiff and attorney "chose to estimate" the value of the fee in the form of a fixed percentage of a contingent recovery did not make the claim valueless at the time when the plaintiff hired the attorney:

That the partnership assigned a portion of its condemnation recovery to its attorney before it knew the exact amount of the recovery does not mean that this amount never belonged to the partnership; it means simply that the attorney and client chose to

Bank, Devaluing Reform: The Derivatives Market and Executive Compensation, 7 DePaul Bus L J 301, 315 (1995).

36 Horst, 311 US at 114-15.

37 Id at $119-20$.

38 Id at $115-17$ (explaining that the taxpayer's personal receipt of income is not the only way to measure realization).

39 See Part III.A.1.

40 See id.

$41 \quad 43$ F3d 1451 (Fed Cir 1995).

42 See Part I.B for an overview of the assignment of income doctrine.

43 Baylin, 43 F3d at 1454-55. 
estimate the value of the attorney's services by tying the fee to the ultimate recovery and by having the obligation of the client to the attorney discharged by having the state pay the attorney his fees directly from the recovery.

Thus, the Federal Circuit deviated from the Fifth Circuit, which reasoned in Cotnam v Commissioner that the plaintiff "could never have collected anything or have enjoyed any economic benefit unless she had employed attorneys" to do so. ${ }^{46}$ The contrast between Baylin and Cotnam demonstrates that a court's view of the value of a legal claim shapes whether or not it believes the assignment of income doctrine applies to contingent fee contracts.

The Federal Circuit is not alone in denying exclusion on the basis of the assignment of income doctrine. The United States Tax Court has refused to permit exclusion of contingent attorneys' fees in all cases except those that may be appealed to the Fifth Circuit or Eleventh Circuit. $^{48}$ Most recently, in Kenseth $v$ Commissioner, ${ }^{49}$ the Tax Court reaffirmed its general position against exclusion. ${ }^{50}$ Unlike the Fifth Circuit, the Tax Court emphasized the control a plaintiff maintains over his claim: the plaintiff can agree to a settlement or even discharge his attorney, thereby canceling the assignment to that attorney. ${ }^{51}$ The court rejected the argument that the claim was speculative and valueless without the aid of an attorney: "Attorney's fees, contingent or otherwise, are merely a cost of litigation in pursuing a client's personal rights. ... The entire ADEA award was 'earned' by and owed to petitioner, and his attorney merely provided a service and assisted in realizing the value already inherent in the cause of action." ${ }^{53}$ In dissent, one judge argued that the assignment of income doctrine is judge-

44 Id at 1455.

45263 F2d 119 (5th Cir 1959). A full discussion of the holding and reasoning of Cotnam can be found in Part II.B.1.

46 Id at 126.

47 In Part III.A, this Comment argues that an attorney increases the value of the legal claim. An individual cannot assign the proceeds from the increased value to the attorney because the proceeds would not exist if not for the attorney's efforts.

48 The "Golsen rule" requires the Tax Court to follow "a Court of Appeals decision which is squarely in point where appeal from our decision lies to that Court of Appeals and to that court alone." Golsen v Commissioner, 54 Tax Ct 742, 757 (1970), affd 445 F2d 985 (10th Cir 1971). See also Davis v Commissioner, 76 Tax Ct Mem Dec (CCH) 46, 48 (1998), affd as Barlow-Davis v Commissioner, 210 F3d 1346 (11th Cir 2000) (permitting exclusion pursuant to Golsen rule because case was appealable to Eleventh Circuit which has followed the Cotnam reasoning).

49114 Tax Ct 399 (2000), affd, 2001 US App LEXIS 17445 (7th Cir).

$50 \quad 114$ Tax $\mathrm{Ct}$ at 412 .

51 Id at 414-16.

52 For this argument, see Estate of Clarks v United States, 202 F3d 854, 857 (6th Cir 2000) (stating that "the value of taxpayer's lawsuit was entirely speculative and dependent on the services of counsel").

53 Kenseth, $114 \mathrm{Tax} \mathrm{Ct}$ at 413. 
made law and that courts can "interpret, refine, and distinguish" to decide whether the conditions for application of the doctrine exist. ${ }^{\text {s4 }}$

The Seventh Circuit also joined the Federal Circuit recently by affirming the Tax Court's Kenseth decision. ${ }^{55}$ According to the Seventh Circuit, the taxpayer violated Lucas $v$ Earl by assigning a portion of his income, which is different from assigning a contract or an incomegenerating asset. Although the court recognized that "contingent compensation constitutes the recipient a kind of joint venturer of the payor," ${ }^{, 57}$ the court concluded that contingent fees are a litigation expense that a taxpayer may deduct (where permissible) but may not exclude. ${ }^{58}$

\section{B. The State Law Approach}

Some courts use state law to examine the exclusion question. State law itself is quite varied and the interpretations and applications can differ dramatically depending upon the text of the individual statute or the common law tradition. A few major state law interpretations, however, help guide most federal court analysis.

1. Cotnam: The statutory attorney's lien.

In Cotnam, Ethel Cotnam reported as gross income only the segment of her $\$ 120,000$ judgment that she kept after subtracting her contingent attorneys' fees. ${ }^{59}$ The Fifth Circuit permitted exclusion on the basis of an Alabama statute that created a charging attorney's lien. ${ }^{60}$ A charging attorney's lien gives an attorney the right to a portion of any money or property obtained in litigation through the attorney's efforts. ${ }^{61}$ A lien is a security interest; it is not an ownership stake.

At the time, the Alabama statute stated:

Upon suits, judgments, and decrees for money, [attorneys] shall have a lien superior to all liens but tax liens, and no person shall be at liberty to satisfy said suit, judgment or decree, until the lien or claim of the attorney for his fees is fully satisfied; and attor-

54 Id at 427 (Beghe dissenting).

55 Kenseth, 2001 US App LEXIS 17445 at *1.

56 Id at *6-7.

57 Id at *5.

58 Id at *10.

$59263 \mathrm{~F} 2 \mathrm{~d}$ at 121.

60 Id at 125.

61 Charles W. Wolfram, Modern Legal Ethics 558 (West 1986).

62 Benci-Woodward v Commissioner, 219 F3d 941, 943 (9th Cir 2000), cert denied, 531 US 1112 (2001) (stating that "an attorney lien does not confer any ownership interest upon attorneys" and is merely a security interest in the litigation proceeds). 
neys at law shall have the same right and power over said suits, judgments and decrees, to enforce their liens, as their clients had or may have for the amount due thereon to them. ${ }^{63}$

The key part of the statute comes after the semicolon: in order to enforce the lien, the attorney possesses the "same right and power over" the suits and judgments as his client. ${ }^{64}$ This enforcement right converted the attorney's security interest into an ownership interest. The court concluded that the portion of the judgment upon which the attorney had his enforceable lien should be excluded from the plaintiff's gross income. ${ }^{65}$ In sum, the rule from Cotnam equates to the following: when a statute gives an attorney equal rights to proceeds from a judgment or settlement, exclusion is appropriate.

Other courts, however, have used state property law as the basis for denying an exclusion. For example, in Coady v Commissioner, ${ }^{66}$ the Ninth Circuit held that the Alaska Code does not give an attorney an ownership interest in a plaintiff's cause of action. ${ }^{67}$ Unlike the Alabama statute, the Alaska statute does not grant an attorney any rights or powers over the income generated by a lawsuit. ${ }^{68}$ The entire judgment was therefore income to the plaintiff, so the court denied the taxpayer's exclusion.

Missouri's attorney's lien statute has also been distinguished from Alabama's statute. Missouri's statute reads:

63 Cotnam, 263 F2d at 125 n 5, quoting 46 Ala Code $\S 64(2)$ (1940). The current Alabama attorney's lien statute employs almost exactly the same language. See Ala Code $\$ 34-3-61$ (1975).

6446 Ala Code $\S 64(2)$.

65 Cotnam, 263 F2d at 125.

66213 F3d 1187 (9th Cir 2000), cert denied, 2001 US LEXIS 2936.

67 Id at 1190.

68 Alaska Stat $\$ 34.35 .430$ (Michie 2000). The statute states:

(a) An attorney has a lien for compensation, whether specially agreed upon or implied, as provided in this section

(1) first, upon the papers of the client that have come into the possession of the attorney in the course of the professional employment;

(2) second, upon money in the possession of the attorney belonging to the client;

(3) third, upon money in the possession of the adverse party in an action or proceeding in which the attorney is employed, from the giving of notice of the lien to that party;

(4) fourth, upon a judgment to the extent of the costs included in the judgment or, if there is a special agreement, to the extent of the compensation specially agreed on, from the giving of notice of the lien to the party against whom the judgment is given and filing the original with the clerk where the judgment is entered and docketed.

(b) This lien is, however, subordinate to the rights existing between the parties to the action or proceeding.

Id.

${ }^{69} 213$ F3d at 1191. 
The compensation of an attorney or counselor for his services is governed by agreement, express or implied, which is not restrained by law. From the commencement of an action or the service of an answer containing a counterclaim, the attorney who appears for a party has a lien upon his client's cause of action or counterclaim, which attaches to a verdict, report, decision or judgment in his client's favor, and the proceeds thereof in whosesoever hands they may come; and cannot be affected by any settlement between the parties before or after judgment.

According to the Tax Court, this statute stands in "marked contrast" to the Alabama statute because the Missouri statute "does not give attorneys the same right and power over suits, judgments, and decrees as their clients had or may have.",

The Federal Circuit also rejected the argument that Maryland law created a lien similar to that held by the attorney in Cotnam. Maryland law recognized a charging attorney's lien, but it did not afford an attorney rights equal to his client's in the proceeds from a judgment or settlement: "Like any other lien, this lien does not create an ownership interest in the attorney, but merely places a charge upon the fund as security for the debt which is owed to the attorney by his client.",

Courts' interpretations of the statutes in Alaska, Missouri, and Maryland demonstrate that some courts take the language of the Alabama statute to be the only language that permits exclusion. Part III questions whether this interpretation of Cotnam is correct in light of the realities and the unique nature of the contingent fee scenario.

\section{Clarks: The common law attorney's lien.}

In Estate of Clarks $v$ United States, ${ }^{74}$ the plaintiff excluded from his gross income the portion of his contingent attorneys' fees that he could not deduct as compensatory damages. ${ }^{75}$ The court relied on an attorney's lien created by Michigan law; however, unlike the statutory attorney's lien in Cotnam, Michigan's attorney's lien arose from common law. ${ }^{76}$ The Sixth Circuit held that the Michigan common law lien

70 Mo Ann Stat $\$ 484.130$ (West 1987).

71 Hukkanen-Campbell v Commissioner, 79 Tax Ct Mem Dec (CCH) 2122, 2126 (2000).

72 See Baylin, 43 F3d at 1454-55. A Maryland statute gives an attorney a lien on "attorney's fees and compensation specifically agreed on." Md Bus Occ \& Prof Code Ann § 10-501 (1989).

73 Baylin, 43 F3d at 1455, citing Chanticleer Skyline Room, Inc v Greer, 271 Md 693,319 A2d 802, 806 (1974) (emphasis added by the Federal Circuit).

74202 F3d 854 (6th Cir 2000).

75 Id at 855. For a discussion of the attorneys' fees that an individual can deduct under the Tax Code, see Part I.A.

76202 F3d at 856. 
operated in the same manner as the Alabama statutory lien. ${ }^{n}$ The language of the Michigan common law case on which the Sixth Circuit relied, however, did not resemble the Alabama statute from Cotnam. Rather, the principle of the Michigan lien, as described by Michigan case law, is as follows: "[T]he agreement amounts to an assignment of a portion of the judgment sought to be recovered or expected as the fruit of the litigation." Cotnam's statutory language; in no Michigan common law case does a court state that attorneys have the same right and power over suits, judgments and decrees as have their clients. In fact, the Michigan case law could be interpreted to mean that the contingent fee contract is an assignment of the judgment, which would violate the assignment of income doctrine and lead to a denial of the exclusion of the fees. ${ }^{79}$

The Sixth Circuit further explained its decision to permit exclusion on the basis that the attorney entered into a joint venture with the taxpayer. ${ }^{80}$ They sought together to win a common pool of monies, and they contracted ex ante to decide how the pool would be divided.

The Sixth Circuit followed the Cotnam reasoning and distinguished the attorney from the wife in Earl and from the son in Horst; the attorney provided a valuable service in order to earn his share of the income rather than simply receiving it as a gift.

This Comment argues that this distinction is especially important because, without the attorney's efforts, the attorney would receive nothing. In Earl, Corliss, and Clifford, on the other hand, the income each donee received might have fluctuated or been speculative at some point, but any uncertainty regarding the income to be assigned in those cases was due to factors unrelated to the donee.

\section{Srivastava: State law appears irrelevant.}

In Srivastava $v$ Commissioner, ${ }^{82}$ the Fifth Circuit reaffirmed its holding in Cotnam in favor of exclusion despite reservations about Cotnam's reasoning and key differences in the state statute. ${ }^{83}$ Srivastava questioned several of Cotnam's premises. The court found no reason to believe that Congress either intended to subsidize only contingent fee agreements, or that the plaintiff did not gain from the

77 Id.

78 Dreiband $v$ Candler, 166 Mich 49, 131 NW 129, 129 (1911).

79 See Part IV.B.

80 Clarks, $202 \mathrm{~F} 3 \mathrm{~d}$ at 857

81 See id ("Like an interest in a partnership agreement or joint venture, Clarks contracted for services and assigned his lawyer a one-third interest in the venture in order that he might have a chance to recover the remaining two-thirds.").

$82220 \mathrm{~F} 3 \mathrm{~d} 353$ (5th Cir 2000).

83 Id at 357-64. 
portion paid to the attorney, or that the contingent fee structure allocated control over the claim completely to either the plaintiff or the attorney. ${ }^{84}$ Furthermore, the Texas law applicable in Srivastava did not track the language of the Alabama statute, which was the foundation for exclusion in Cotnam. The Fifth Circuit described the Texas common law attorney's lien as follows: "[T]he lawyer's rights, based on the contingent fee contract, are wholly derivative from those of his client. The attorney-client relationship is one of principal and agent. Therefore, the rights of each in a cause of action during the existence of that relationship are necessarily ... interwoven with the other."

Because of the principal-agent relationship, an attorney in Texas could not have the equivalent protection that the Alabama statute confers - the same rights and powers as his client over the proceeds from a judgment. The Fifth Circuit, however, disregarded the lien because the court believed that the lien addressed the relationship between the defendant, who will actually pay the proceeds, and the attorney. ${ }^{86}$ The court stated that the relevant relationship to answer the exclusion question is that of the plaintiff vis-à-vis his attorney. ${ }^{87}$ Following this rationale, the Fifth Circuit demoted the charging attorney's lien from its lofty status as the impetus for exclusion to the level of total insignificance. This latest holding and reasoning leaves courts without a structured approach to the exclusion question. The next part of the Comment attempts to create some of this much-needed structure.

84 Id.

85 Id at 368 (Dennis concurring in part and dissenting in part) (internal quotation marks omitted), quoting Dow Chemical Co v Benton, 163 Tex 477, 357 SW2d 565, 567 (1962).

86 Srivastava, 220 F3d at 363-64.

87 Id.

88 In the end, however, the court held that it must follow Cotnam because Srivastava was "substantially indistinguishable." Id at 357. As a procedural matter, Cotnam can only be overruled if the Fifth or Eleventh Circuit sits en banc. See Kenseth, 114 Tax Ct at 412 n 6.

The Fifth Circuit is the only circuit that has had the opportunity to decide this issue based on divergent state laws on attorney's liens, yet the circuit did not let state law dictate the outcome. Srivastava, 220 F3d at 357-58. The court's arguments against Cotnam demonstrate that the court could have denied exclusion by staying true to the reasoning of Cotnam: state law is determinative.

Another court - the Tax Court - also appears to take the stance that state law plays no role in the exclusion question. Unlike the Fifth Circuit, however, which has held for exclusion, the Tax Court holds against exclusion. In O'Brien $v$ Commissioner, the Tax Court said that even an "irrevocable assignment of a portion" of a future recovery would violate the assignment of income doctrine. 38 Tax Ct 707, 712 (1962), affd, 319 F2d 532 (3d Cir 1963). The Tax Court found that the Internal Revenue Code was not intended to turn on such "refinements" as the existence of an attorney's lien. Id. This statement harkens back to the Supreme Court's statement in Corliss that taxation is not concerned with "refinements of title" but rather with "actual command over the property taxed." 281 US at 378 . So even if state law mandated an irrevocable assignment of an attorney's portion of a judgment, the Tax Court would disallow exclusion. 


\section{FINDING THE HEART OF THE CONTINGENT FEE RELATIONSHIP}

There are two problems with the approaches courts have taken in addressing whether contingent attorneys' fees should be excluded from gross income. First, the taxpayer-client lacks control over the proceeds to which his attorney is entitled, and control is required for the anticipatory assignment of income doctrine to apply. Second, although courts often turn to state law to define federally taxable property interests, state lien laws were not written with the exclusion of contingent fees in mind. Consequently, they provide little assistance to courts.

\section{A. Control and the Inapplicability of the Assignment of \\ Income Doctrine}

The essence of the assignment of income doctrine is control. ${ }^{89} \mathrm{Be}-$ ginning with Earl and continuing through Clifford and Horst, the Supreme Court clarified that the assignor's control of income determines whether he can escape taxation by assigning this income to another taxpayer. ${ }^{90}$ In Earl, the husband created the income; his wife received nothing from the contract unless he earned income." In Clifford, the taxpayer owned a reversion in the trust from which the income was paid. ${ }^{92}$ In Horst, the taxpayer retained the principal of the bond while distributing the bond's coupons. ${ }^{93}$ Control is the litmus test for taxation because the taxpayer derives a benefit from control.

The most important determination, therefore, is whether the taxpayer-client relinquished control of part of his claim by entering into a contingent fee contract. This Comment proposes that he never controlled the attorney's portion of the judgment or settlement. The assignment of income doctrine, therefore, should not apply, and he should be able to exclude the attorneys' fees.

\section{The legal claim has no value until the moment of judgment or settlement.}

Some courts view the taxpayer-client as a principal who controls the legal claim and the attorney as his agent who derives a right to income from his claim. In this model, the attorney has no ownership stake in the claim. ${ }^{94}$ Any exclusion of attorneys' fees would therefore

89 For a discussion of the evolution of the anticipatory assignment of income doctrine, see Part I.B.

90 Earl, 281 US at 114-15; Horst, 311 US at 114.

91281 US at 113-14.

92309 US at 332-33.

93311 US at 114-15.

94 See, for example, Michigan Mutual Insurance Co v Smoot, 129 F Supp 2d 912, 923 (E D 
violate the assignment of income doctrine. Compare, for example, the contingent fee arrangement to the assignments in Horst and Clifford." Because the taxpayer in Horst retained the principal of his bond and derived a benefit from presenting the coupon bond as a gift to his son, he violated the assignment of income doctrine. ${ }^{6}$ In the contingent fee case, the client retains the majority of the legal claim while assigning a small portion of the claim to his attorney, a situation very similar to the coupon bond Horst assigned to his son. In Clifford, the assignment of income from the taxpayer's trust to his family violated the doctrine because the taxpayer's reversionary interest in the trust gave him residual control." Similarly, in the contingent fee setting, the client has what could be considered a reversion on his legal claim: he can remove the claim from the attorney at any time, and he retains the final decision regarding settlement."

The contingent fee arrangement, however, is more complex. First, a plaintiff has a significantly better chance of maximizing proceeds from a legal claim if he hires an attorney. One empirical study found that consumers of legal work are more likely to hire attorneys as the consumers' legal claims increase in factual or legal complexity. ${ }^{99}$ Another study found that advocates with advocacy experience and substantive experience are likely to be the most successful advocates. ${ }^{100}$ Commentators without empirical evidence have reached the same conclusion that self-represented litigants are disadvantaged compared to attorneys. When a self-represented litigant must advocate against an attorney, the self-represented litigant is substantively disadvan$\operatorname{taged}^{101}$ and is susceptible to unethical behavior. ${ }^{102}$ Furthermore, the

Va 2000) (referring explicitly to attorney and client as principal and agent respectively). See also Kenseth, $114 \mathrm{Tax} \mathrm{Ct}$ at 413 ("Attorneys represent the interests of clients in a fiduciary capacity. It is difficult, in theory or fact, to convert that relationship into a joint venture or partnership.").

95 See Part I.B for a discussion of Horst and Clifford.

96311 US at $119-20$.

97309 US at 335.

98 See Model Rules of Professional Conduct Rule 1.2(a) (ABA 2000) ("A lawyer shall abide by a client's decision whether to accept an offer of settlement of a matter."). See also Kenseth, 114 Tax Ct at 414-16 (explaining that Cotnam did not address the fact that a tort plaintiff has continuing control with respect to settlement of his legal claim and has the power to discharge his attorney). But see F.B. MacKinnon, Contingent Fees for Legal Services: A Study of Professional Economics and Responsibilities 196 (Aldine 1964) (explaining that as a practical matter attorneys have control of settlement and strategy in contingent fee cases).

99 Steven R. Cox and Mark Dwyer, A Report on Self-Help Law: Its Many Perspectives 21, 24 (ABA 1987).

100 Herbert M. Kritzer, Working Paper, First Thing We Do, Let's Replace All the Lawyers: A Comparison of Lawyers and Nonlawyers as Advocates 5 (Wisconsin 1995). In a study of tax appeal hearings, attorneys won 36 percent of their cases, while non-attorneys won only 15 percent of their cases. Id at 6-7.

101 See Leandra Lederman, Which Cases Go to Trial?: An Empirical Study of Predictors of Failure to Settle, 49 Case W Res L Rev 315, 340 n 131 (1999) (collecting citations to commentators' assertions that "where only one side is represented, pro se litigants are substantively disad- 
Supreme Court has recognized that litigants are better served by hiring counsel than proceeding pro se: “[T]he successful prosecution of meritorious claims is better served by a rule that creates an incentive to retain counsel." ${ }^{103}$

The following example shows how an attorney adding value to a legal claim makes the contingent fee scenario different from Earl and its progeny. Consider a plaintiff who wishes to pursue a legal claim. If he chooses self-representation, he will receive settlement proceeds of $\$ 100,000 .^{104}$ If he hires an attorney, however, he will receive twice that amount in settlement proceeds, or $\$ 200,000$. When the plaintiff actually hires the attorney under a 30 percent contingent fee agreement, the most the plaintiff can possibly assign is $\$ 100,000$ - the maximum value of his claim. The plaintiff, however, will receive $\$ 140,000$ from the settlement because he has hired the attorney; the attorney takes $\$ 60,000$ pursuant to the contingent fee agreement. The $\$ 140,000$ that the plaintiff receives is more than the value of the plaintiff's claim before he hired the attorney. The plaintiff, therefore, did not assign the $\$ 60,000$ to the attorney because the plaintiff never had the $\$ 60,000$. Without the attorney the $\$ 60,000$ never would have arisen as proceeds. The plaintiff simply agreed that the attorney would have an interest in any proceeds that might result from the attorney's pursuance of the legal claim.

What we see is that the control element that was so crucial in Earl and Horst does not exist in the contingent fee situation. Earl assigned his salary to his wife. Even if his salary fluctuated annually, his salary did not depend on whether he assigned it to his wife. Earl was going to get a salary regardless. Horst assigned interest coupons to his sons. Even if the interest payments were based on a changing interest rate, the interest payments did not depend on whether he assigned the coupons to his sons. Horst would get the interest regardless.

vantaged").

102 Russell Engler, Out of Sign and Out of Line: The Need for Regulation of Lawyers' Negotiations with Unrepresented Poor Persons, 85 Cal L Rev 79, 82 (1997) (noting that the ethical rules designed to protect the unrepresented in their dealings with attorneys "routinely go unheeded").

103 Kay v Erhler, 499 US 432, 438 (1991) (disallowing a pro se litigant to receive attorneys' fees because it would "create a disincentive to employ counsel whenever [a pro se litigant] considered himself competent to litigate on his own behalf").

104 A body of literature argues that a market of unmatured tort claims could function, thereby suggesting that a bare claim has value in itself. See Richard A. Epstein, Torts 905-07 (Little, Brown 6th ed 1995) (describing the argument that tort victims could receive immediate and certain compensation by selling claims in a market). But see Marc J. Shukaitis, A Market in Personal Injury Tort Claims, $16 \mathrm{~J}$ Legal Stud 329, 339-40 (1987) (explaining that a market in tort claims could be inhibited if the tort victim lacks incentive to testify accurately and to the best of his ability). 
The fact that a client can fire an attorney during representation does not change the conclusion that there is no assignment of income. It is true that an attorney fired before a judgment could bring a suit in quantum meruit. But that fact does not weaken the argument that the moment of judgment or settlement is the critical point for deciding the exclusion question for contingent fees. Until a judgment or settlement is reached, there is no income that can be subject to federal income tax. But when a judgment or settlement occurs, the attorney gains a contractual right to a portion of the proceeds that did not exist before that point. The attorney's right to those proceeds is strong because courts should give "due deference to the intent of the parties"; ${ }^{105}$ the agreement is the "freely negotiated expression" the client and his attorney to enter into such a contract. It is true that courts can review contingent fee contracts to ensure reasonableness ${ }^{107}$ and, moreover, that contingent fee agreements should not be treated as ordinary commercial contracts. ${ }^{100}$ The baseline, however, is that courts are reluctant to disturb contingent fee agreements because, as the Supreme Court wrote, a "request for attorney's fees should not result in a second major litigation.,"109

Moreover, the contingent fee contract is one in which the attorney's right to his portion of a settlement or judgment is lost only when a court finds his fee was unreasonable. ${ }^{110}$ Once the plaintiff has reached a settlement or judgment, the contingent fee contract will be enforced." Given this right, a plaintiff should not be taxed on his attorney's portion of the judgment or settlement. As the Supreme Court

105 Wells v Sullivan, $907 \mathrm{~F} 2 \mathrm{~d} 367,371-72$ (2d Cir 1990) (stating that there is no per se test for reasonableness of contingent fee agreements and that courts should give the same deference to contingent fee agreements as they would to any contract embodying the intent of the parties).

106 Id at 371. See also Alderman v Pan Am World Airways, 169 F3d 99, 102-03 (2d Cir 1999) (explaining that "[c]ourts should be reluctant to disturb contingent fee arrangements freely entered into by knowledgeable and competent parties"). See also note 2.

107 McKenzie Construction, Inc v Maynard, 758 F2d 97, 100-01 (3d Cir 1985). Courts can also invalidate fraudulent contingent fee agreements. See In re Factor VIII or IX Concentrate Blood Products Litigation, 159 F3d 1016, 1020 (7th Cir 1998) (affirming district court's injunction and declaratory relief against lawyers' enforcement of certain contingent fee contracts).

108 McKenzie Construction, 758 F2d at 101.

109 Hensley $v$ Eckerhart, 461 US 424, 437 (1983) (discussing the nature of the contingent fee agreement in the context of a fee dispute).

110 Northern Heel Corp v Compo Industries, Inc, 851 F2d 456, 475 (1st Cir 1998) ("If lawful-and, generally speaking, contingent fees have not been thought unlawful for well over two decades - the contingent fee should be enforced unless it is unreasonable under the circumstances.") (internal citations omitted).

111 Horrigan $v$ Thompson, 2000 US App LEXIS 22292, *22-23 (6th Cir) (stating that attorneys discharged after settlement should receive their share of a settlement pursuant to their contingent fee agreement with the client, and that the attorneys' recovery was not limited to quantum meruit when they had substantially performed the required legal work, but affirming the district court's denial of their motion to intervene on the grounds that their pursuit of the claim in a parallel state court action was adequate). 
made clear in Corliss, "[T]axation is not so much concerned with the refinements of title as it is with actual command over the property taxed."

\section{An attorney provides a service to access his portion of a judgment or settlement.}

Those who argue for the principal-agent relationship ${ }^{113}$ point out that the attorney's income most often comes from recoveries related to services provided by the plaintiff. ${ }^{114}$ In Cotnam, for example, the plaintiff sought a portion of the estate of a gentleman for whom the plaintiff acted as a caretaker. ${ }^{1.5}$ Such cases compare very favorably to Earl, in which Mr. Earl violated the assignment of income doctrine by assigning wages that he earned or would earn in the future. ${ }^{116}$ If courts view contingent attorneys' fees as income from the plaintiff's wages that he sought to recover in a lawsuit, the fees should be treated as an anticipatory assignment of income."

This model fails, however, because not all contingent fee cases concern recovery of earned wages. For example, Clarks concerned a claim for personal injury damages. ${ }^{118}$ More importantly, the contingent fee scenario is distinguishable because the attorney must provide a service to access his share of a judgment or settlement. The donees from the cases establishing the assignment of income doctrine were involved in intrafamily gift situations. ${ }^{119}$ This is significant not because the donees offered no consideration for their income received, but rather because their actions had nothing to do with whether their income existed in the first place. Even if each donee exchanged something of value for the income he received, the assignors in these cases would have violated the assignment of income doctrine by excluding the assigned income. This is because the assignors controlled the income, even if the income was speculative. In the contingent fee setting,

112281 US at 378 . See also text accompanying notes $29-33$.

113 For the original discussion of the principal-agent idea, see Part III.A.1.

114 See Deborah A. Geier, Some Meandering Thoughts on Plaintiffs and Their Attorneys' Fees and Costs, 87 Tax Notes 531, 538-39 (2000) (discussing the difficulty in differentiating services income and property income).

$115263 \mathrm{~F} 2 \mathrm{~d}$ at $120-21$. See also text accompanying notes 59-60; Coady, $213 \mathrm{~F} 3 \mathrm{~d}$ at 1187 (discussing plaintiff who sought back pay after an allegedly discriminatory termination).

116281 US at 114-15. See also text accompanying notes 24-28.

117 In his dissent in Cotnam, Judge Wisdom explained that the plaintiff earned through her services the entirety of the judgment she hoped to recover. Therefore, she had control over that income, and her assignment of it to her attorneys should not allow her to evade taxation. $263 \mathrm{~F} 2 \mathrm{~d}$ at $126-27$.

118202 F3d at 855. See also Srivastava, 220 F3d at 355-56 (evaluating the exclusion resulting from a legal suit involving a libel claim).

119 In Corliss and Clifford, each taxpayer hoped to dodge income taxation by hiding his income as a gift to a family member. See Part I.B. 
the attorney-not the plaintiff-has earned his portion of the settlement, and the plaintiff should be able to exclude that portion. ${ }^{12}$

\section{Ethical rules recognize an attorney's interest.}

An additional argument is that the American Bar Association's Model Rules of Professional Conduct recognize an attorney's ownership interest in a contingent fee case. Model Rule 1.8(j) states that attorneys cannot acquire a proprietary interest in a cause of action except through a lawyer's lien or in contingent fee cases. ${ }^{121}$ It is true that the ethics rules mandate careful use of contingent fee arrangements. ${ }^{12}$ In particular, the ABA's Comment to Model Rule 1.5 also states that an attorney cannot enter a fee agreement that might induce him to perform his services in a way contrary to his client's interest. ${ }^{123}$ These restrictions, however, do not take away from the fact that an attorney has an ownership interest in a contingent fee case. Moreover, the relevant point of analysis for tax purposes is the moment when a legal claim has been converted into a favorable judgment or settlement ${ }^{124}-$ at that time, any decision by the client to discharge his attorney ${ }^{125}$ cannot divest the attorney of his share of the total recovery as set by the terms of a valid contingent fee contract.

\section{B. The Role of Attorney's Liens Created by State Law}

Rather than recognize an attorney's interest in a judgment or settlement as defined by his contingent fee agreement, many courts use attorney's liens as proxies for an attorney's right to legal fees. A charging lien affords an attorney the right to a portion of the money or other property obtained in litigation through the attorney's efforts. ${ }^{126}$ Many states create a charging lien by statute, ${ }^{127}$ but the lien exists in other states as a function of common law. ${ }^{128}$ The lien covers

120 The attorney-client relationship in a contingent fee scenario can even be viewed as a partnership under the Uniform Partnership Act of 1997 § 101(6), 6 ULA 35 (West Supp 2000) (defining a partnership "as an association of two or more persons to carry on as co-owners a business for profit"). See Letters to the Editor, 88 Tax Notes 1059, 1059 (2000) (letter of Robert W. Wood, arguing that a contingent fee probably satisfies the definition of a partnership under the UPA). See also MacKinnon, Contingent Fees for Legal Services at 196 (cited in note 98) (stating that attorneys have more practical control over contingent fee cases than non-contingent fee cases).

121 Model Rule of Professional Conduct 1.8(j).

122 See Model Code of Professional Responsibility EC 5-7 (ABA 1982) ("[A] lawyer ... should enter into a contingent fee arrangement only in those instances where the arrangement will be beneficial to the client.").

123 Model Rule of Professional Conduct Rule $1.5 \mathrm{cmt} 3$.

124 See Part III.A.1.

125 See Model Rule of Professional Conduct 1.2(a) (stating that the client has the final decision in all matters involving his attorney).

126 See Wolfram, Modern Legal Ethics at 558 (cited in note 61).

127 See, for example, Ala Code § 34-3-61. 
other states as a function of common law. ${ }^{128}$ The lien covers the judgment that the lawyer acquired for his client. ${ }^{129}$ The lien is a security interest; it is less than a proprietary interest. ${ }^{130}$ The client owns the entirety of the underlying judgment, and the attorney has a claim, like a creditor, against a portion of the judgment.

At first, relying on state property law to resolve the exclusion question seems sensible. Although the Internal Revenue Code should be interpreted to apply uniformly across states, ${ }^{131}$ courts determining federal tax law often look to state law to define property interests and, hence, what is taxable: "[I]n the application of a federal revenue act, state law controls in determining the nature of the legal interest which the taxpayer had in the property." ${ }^{, 132}$ Given, however, that an attorney has a powerful right created by contract to a portion of the judgment or settlement, ${ }^{133}$ the use of state law attorney's liens is unnecessary.

The state law approach should also be abandoned because state laws are not instructive or predictive of outcomes; that is, if a court is to rely on a state law in determining the attorney's interest in judgment or settlement proceeds in a contingent fee case, the state law should be relatively clear. The problem is that state lien laws were not created with the exclusion question in mind and are ambiguous with regard to the issue. Two courts could arguably interpret the same statute in completely different ways. Moreover, the Fifth Circuit in Srivastava hesitated to permit an intracircuit split on the application of federal tax law when the two states' lien laws were clearly distinguishable. ${ }^{134}$

\section{State law provides no guidance.}

The Fifth Circuit in Cotnam rested its holding on an Alabama statute that stated, "[A]ttorneys at law shall have the same right and

128 See, for example, Clarks, 202 F3d at 856 (referring to the Michigan attorney's lien as a "common law lien").

129 See People v Keeffe, 50 NY2d 149, 405 NE2d 1012, 1015 (1980).

130 Wolfram, Modern Legal Ethics at 558 (cited in note 61). Part III.A argued that the attorney's interest in a contingent fee arrangement is more like a proprietary interest than a lien. If that proposition is correct, then the nature of the attorney's lien should not affect the exclusion question.

131 Burnet $v$ Harmel, 287 US 103, 110 (1932) ("[T] he will of Congress ... is to be interpreted so as to give a uniform application to a nationwide scheme of taxation.").

132 Morgan v Commissioner, 309 US 78, 82 (1940). See, for example, Poe v Seaborn, 282 US 101,110 (1930) (using Washington law to determine property interest of taxpayer); Greer $v$ United States, 207 F3d 322, 327 (6th Cir 2000) (examining Kentucky law to determine nature of tort claim in determining whether damages are excludable); Green v Commissioner, 855 F2d 289, 292 (6th Cir 1988) ("Although the property interests of divorcing parties are determined by state law, federal law governs the federal income tax treatment of that property.").

133 See Part III.A.1.

134220 F3d at 363-65 \& n 33. 
power over said suits, judgments and decrees, to enforce their liens, as their clients had or may have for the amount due thereon to them."135 This clause, the court determined, recognized that attorneys have an ownership interest in a legal claim. The argument that attorneys have an ownership interest in a contingent fee scenario is a powerful one. ${ }^{130}$ However, the argument that this particular statutory language provides conclusive evidence of an attorney's ownership interest is questionable. An explicit grant of a proprietary interest in the legal claim to the attorney might be a more direct and unambiguous method of establishing an ownership interest.

Cotnam's reliance on that particular statutory language transformed the phrase "the same right and power over said suits, judgments and decrees" into magic words that confine courts' interpretations of lien statutes. For example, consider Maryland's lien statute, which states that an attorney has a lien on both "an action or proceeding of a client" ${ }^{, 137}$ and "a judgment or award that a client receives." "It would be sensible to think that in order for an attorney to exercise these rights, the statute must grant the attorney rights equal to those of his client.

The same logic can be applied in the interpretation of Missouri's lien statute. ${ }^{139}$ In Hukkanen-Campbell v Commissioner, ${ }^{140}$ the Tax Court distinguished the Missouri statute from the Alabama statute on which Cotnam relied: "Although both provisions give an attorney a lien to secure his or her compensation, the Missouri provision ... does not give attorneys the same right and power over suits, judgments, and decrees as their clients had or may have." ${ }^{141}$ The statute recognizes that an attorney's compensation for services is "governed by agreement, express or implied." ${ }^{\text {, }}$ If this is interpreted as a recognition of the attorney's strong contractual interest in the proceeds, ${ }^{143}$ then it would not be unreasonable to interpret the entire statute as giving, in a contingent fee scenario, an attorney an interest tantamount to ownership.

Another example is Nebraska's attorney's lien statute, which reads, "An attorney has a lien for a general balance of compensation ... upon money ... in the hands of the adverse party in an action or proceeding in which the attorney was employed." ${ }^{\text {,4t }}$ The statute spe-

263 F2d at 125 n 5, citing 46 Ala Code $§ 64(2)$.

See Part III.A.1.

Md Bus Occ \& Prof Code Ann $\$ 10-501(a)(1)(2000)$.

Id $\S 10-501(\mathrm{a})(2)$.

See text accompanying note 70 .

14079 Tax Ct Mem Dec (CCH) 2122 (2000).

141 Id at 2126.

142 Md Bus Occ \& Prof Code Ann § 10-501(a)(1).

143 See text accompanying notes 105-12.

144 See Petersen v Commissioner, 38 Tax Ct 137, 152 (1962). 
cifically points out money in the hands of the adverse party, thereby indicating that it is at least plausible that the plaintiff is never going to get that money - that is, in a dispute, the attorney will get it first. But, the statute does not contain the Cotnam magic words.

Consider also the Alaska lien statute that the Ninth Circuit interpreted in Coady. ${ }^{145}$ The Alaska statute states that an attorney has a lien "upon money in the possession of the adverse party in an action or proceeding in which the attorney is employed." this phrase alone might presume that a charging attorney's lien implies or even necessitates that the attorney will have an equivalent power over his client's judgment to enforce his lien. The last line of the statute, however, states: "This lien is, however, subordinate to the rights existing between the parties to the action or proceeding." ${ }^{147}$ This is certainly a clear statement that a litigant has priority vis-à-vis his attorney to a portion of proceeds from a judgment or settlement. However, if the attorney has a contractual interest tantamount to a proprietary interest, as Part III.A argues, then the final line of the Alaska statute does not apply to the proceeds due to the attorney pursuant to the contingent fee agreement. The plaintiff has a superior right vis-àvis his attorney for the 60 percent of the judgment due to the plaintiff, but the attorney has a superior right vis-à-vis his client for the attorney's 40 percent. This interpretation is obviously a matter of opinion, but holding a court to the Cotnam magic words makes such an interpretation - a plausible interpretation-impossible to reach.

The situation becomes more confusing because not all attorney's liens are based on statutes. ${ }^{148}$ Consider Wisconsin law, which recognizes a common law charging attorney's lien that appears "broadly to be a remedy to prevent unjust enrichment to a client whose attorney has performed well and secured a judgment." ${ }^{\text {,199 }}$ On its face, this common law lien arguably should give an attorney the same rights to a portion of the judgment as his unjustly enriched client.

The common law liens of some other states are also open to interpretation. For example, the Ninth Circuit characterized the California common law attorney's lien as follows:

[A]n attorney ... acquires no more than a professional interest. To hold that a contingent fee contract or any 'assignment' or 'lien' created thereby gives the attorney the beneficial rights of a real party in interest, with the concomitant personal responsibil-

145213 F3d at 1190 . See text accompanying notes $66-68$ for a discussion of Coady.

146 Alaska Stat $\$ 34.35 .430$ (a)(3).

147 Id.

148 See Part II.B.2.

149 Matter of Richland Building Systems, Inc, 40 BR 156, 158 (Bankr W D Wis 1984). 
ity of financing the litigation, would be to demean his profession. ${ }^{150}$

This statement is ambiguous in light of the fact that the ethical rules of the legal profession, the ABA's Model Rules, explicitly recognize that attorneys have ownership interests in contingent fee contracts. ${ }^{151}$ A "professional interest," using the terminology of the Ninth Circuit, could certainly be considered to be an ownership interest even if the Ninth Circuit feels it would demean the legal profession.

Consider also Pennsylvania's common law attorney's lien. The Tax Court held that the Pennsylvania common law lien does not create an ownership interest for an attorney. ${ }^{152}$ The only case the Tax Court cited to support this holding, however, was an 1852 case. ${ }^{153}$ The Tax Court's ruling came over one hundred years later, in 1968. The Tax Court said that an attorney in Pennsylvania keeps "only those proceeds of the judgment which come within his possession in an amount equal to reasonable compensation for his services." ${ }^{154}$ That statement could fit within the framework of an attorney having an ownership interest in the proceeds of a settlement or judgment. ${ }^{155}$ An ownership interest in settlement or judgment proceeds becomes more likely when one considers that the Pennsylvania lien operates such that "[a] court will endeavor to protect attorneys who claim fees from a fund created largely, if not entirely, by their efforts." ${ }^{\text {,156 }}$ If the lien is truly about protecting attorneys who receive proceeds only when they generate them through their efforts, an ownership interest is a reasonable interpretation of the lien.

The point here is not so much that one interpretation is correct and another is incorrect. The point is that these liens are completely ambiguous and can be interpreted either for or against taxpayers.

Attorney's lien laws vary in certain respects from state to state. The states may differ in how they treat attorney's rights to the judgments vis-à-vis other creditors. ${ }^{1.7}$ States also disagree over whether an attorney's lien takes precedence over a set-off judgment. ${ }^{158}$ These dif-

150 Benci-Woodward v Commissioner, 219 F3d 941, 943 (9th Cir 2000), quoting Isrin v Superior Court, $63 \mathrm{Cal} 2 \mathrm{~d} 153,403 \mathrm{P} 2 \mathrm{~d}$ 728, 732-3 (1965).

151 See Part III.A.3.

152 Estate of Gadlow v Commissioner, 50 Tax Ct 975, 980 (1968).

153 Id, citing Balsbaugh $v$ Frazer, 19 Pa 95, 99 (1852).

154 Estate of Gadlow, 50 Tax $\mathrm{Ct}$ at 980.

155 Id.

156 Turtle Creek Bank \& Trust Co v Murdock, 157 Pa Super 528, 43 A2d 554, 556 (1945).

157 Compare Local 58, IBEW v G.T. Einstein Electric, Inc, 932 F Supp 974, 979 (E D Mich 1996) (holding that a Michigan charging lien was subject to other liens perfected prior in time), with Brooks v Cash \& Thomas Contractors, Inc, 137 Ga App 176, 223 SE2d 225, 227 (1976) (finding that a statutory attorney's lien in Georgia was superior to all other liens except tax liens).

158 A set-off judgment entitles a debtor to reduce the amount of a debt by any sum that a 
ferences, however, are with respect to other third parties, and they provide no guidance in regards to an attorney's proprietary interest in a legal claim and his relationship vis-à-vis his client. If there is legislative history covering attorney's liens, courts do not cite it; courts and commentators do, however, agree that the attorney's lien was "invented by the courts for the protection of attorneys against the knavery of their clients, by disabling clients from receiving the fruits of recoveries without paying for the valuable services by which the recoveries were obtained." attorney's lien statutes and common law attorney's liens in the manner that best protects attorneys. If liens are to protect attorneys against their clients, the default rule should be equal rights for attorneys and clients.

2. The case law demonstrates that state law is neither instructive nor predictive of outcomes.

Because state law is unclear on the nature of the attorney's stake in a legal claim, a court can reach any conclusion it wishes by its interpretation of state law. First, consider again Clarks. ${ }^{160}$ The Sixth Circuit permitted exclusion based on this excerpt from a Michigan court opinion: "the [contingent fee] agreement amounts to an assignment of a portion of the judgment sought to be recovered." ${ }^{161}$ Not only does this language fail to mirror the statutory language in Cotnam, but also it could reasonably be interpreted to mean that the contingent fee contract is an assignment of the judgment, which would violate the assignment of income doctrine. A plausible view of the Clarks holding is that the Sixth Circuit felt that exclusion should be permitted, as evidenced by its enthusiastic endorsement of the "joint venture" approach, ${ }^{162}$ so it liberally interpreted state law to reach that end.

State law also provides little guidance in the Ninth Circuit's ruling in Coady. The Alaska statute provides that an attorney has a lien

creditor owes the debtor. Compare Ramsey v Sumner, 211 Ga App 202, 438 SE2d 676, 678 (1993) (finding an attorney's lien arising under a Georgia statute superior to a set-off judgment) with United States Fidelity \& Guaranty Co v Levy, 77 F2d 972, 975 (5th Cir 1935) (stating that in Alabama, as between a set-off judgment and an attorney's lien, the first claim filed was superior).

159 Clarks, 202 F3d at 856, citing Ray Andrews Brown, The Law of Personal Property $\$ 116$ at 559 (Callaghan 2d ed 1955). See also Robert L. Rossi, 2 Attorneys' Fees 247 (Law Coop 1995) (stating that attorney's liens are based on the equitable concept that an attorney should be paid from the proceeds he obtained).

160202 F3d at 854.

161 Id at 856 (internal quotation marks omitted), quoting Dreiband $v$ Candler, 166 Mich 49, 131 NW 129, 129 (1911).

162202 F3d at 857-58 (stating that the lawyer has become a "tenant in common" with his client, and the income should be charged to the lawyer because the lawyer is the one who earned it and received it). 
"upon money in the possession of the adverse party in an action or proceeding in which the attorney is employed." strue this provision to give an attorney the same right as his client to the adverse party's assets, which would make the provision similar to the Cotnam statute and permit exclusion. The Ninth Circuit disallowed exclusion, however, pointing to a different part of the statute that seems to deal with retaining liens rather than charging liens. ${ }^{164}$ The court also referenced an Alaskan case to support the proposition that Alaska law "does not confer any ownership interest upon attorneys or grant attorneys any right and power over the suits, judgments, or decrees of their clients." clients retain primary control of settlement of legal claims. ${ }^{166}$ There is nothing in the case indicating that a lawyer has no ownership interest in the claim, especially at the moment when a settlement or judgment has been legally entered.

Finally, consider Srivastava, in which the Fifth Circuit had the perfect opportunity to uphold the importance of state law in the exemption question, following the reasoning of Cotnam. ${ }^{167}$ Even though the applicable Texas law did not clearly give attorneys the same rights over judgments as their clients, the court nonetheless permitted exclusion, claiming it must follow the holding in Cotnam. ${ }^{168}$ The reasoning in Cotnam, however, was that state law determined the attorney's ownership interest. If courts permit exclusion even when state law does not give an attorney an ownership interest like that in Cotnam, state law appears to play no role in the exclusion determination. One plausible reading, therefore, is that the Fifth Circuit essentially chose to have a consistent rule (exclusion in all cases) that may be problematic rather than a rule (following state law) that generates inconsistent outcomes. The price of state-to-state variation proved to be too much.

The Fifth Circuit might very well hesitate to create an intracircuit split on federal income tax application in this particular situation. Although intracircuit splits based on divergent state laws are not uncommon, the attorney's liens created by state law, as Part III.B argues, do not speak to the issue of exclusion of contingent fees. Because of the lack of clarity of these state laws, the court might find it anomalous for a plaintiff to be permitted to exclude millions of dollars in one

163 Alaska Stat § 34.35.430.

164 Coady, 213 F3d at 1190. Contingent fee contracts give rise to charging liens, not retaining liens. See text accompanying notes 126-30.

165 Coady, 213 F3d at 1190, citing Hagans, Brown \& Gibbs v First National Bank of Anchorage, 783 P2d 1164, 1168 (Alaska 1989).

166 Id at 1168.

$167220 \mathrm{~F} 3 \mathrm{~d}$ at $363-65$.

168 See Part II.B.3. 
state, such as Alabama, but be restricted from excluding in another state in the same circuit, such as Texas.

\section{Reliance on state law might necessitate exclusion of all legal fees.}

Statutes like Alabama's, under which the attorney has the same rights and powers over a judgment as has his client, arguably call for exclusion of any judgment for all plaintiffs whether they hired their attorneys on an hourly fee or on a contingent fee. It makes sense, however, that contingent fees should be excluded but hourly fees should not. A client who hires an attorney by paying hourly fees receives all proceeds from a judgment or settlement; the client is willing to commit to pay legal fees by the hour and receive all proceeds. On the other hand, as this Comment has argued, the contingent fee attorney creates the proceeds he receives from a settlement or judgment, so the tax system should not treat the contingent fee client as having received the attorney's proceeds as the client's income.

One might argue that if a plaintiff is taxed upon an entire judgment if he pays an hourly fee, but a plaintiff is not taxed upon an entire judgment if he agrees to a contingent fee, then a rational plaintiff would never use hourly fees. There are three responses: First, the attorney paid hourly may provide better representation because she does not have to worry about investing time for zero payoff. ${ }^{169}$ Second, the attorney who can charge by the hour may be a better attorney than the attorney who has yet to prove herself and must enter contingent fee agreements to attract clients. ${ }^{170}$ Third, this concern may not occur frequently because attorneys who charge hourly fees may only serve clients who can pay the fees prior to judgment or settlement. If an attorney knows that her fees depend on reaching a judgment or settlement, and she can receive a larger premium through contingent fees, then she will try to use contingent fees rather than hourly fees."

169 One concern with contingent fees is that attorneys may charge an excessive fee in relation to the effort they provide. See Robert L. Rossi, 1 Attorneys' Fees 97-98 (Law Coop 2d ed 1995).

170 This is merely a conjecture that some attorneys prefer hourly fee contracts because of the certainty of payment, and most of the attorneys who can attract clients to pay hourly fees are those who have succeeded in previous cases and therefore have a good reputation.

171 There is an additional policy argument that contingent fee clients are often individuals who lack the funds to pay hourly fees. In each case, such individuals must calculate whether it is better (1) to pay a premium and hire on a contingent fee and not get taxed, or (2) to pay hourly and not pay a premium and get taxed. (There is a risk premium that the contingent fee lawyer charges.) Large, institutional clients will have the ability to make this calculation. Individuals injured in personal injury situations will be less able to make this calculation, and these individuals will be forced to choose the contingent fee attorney. The policy argument is that such individuals should be able to exclude contingent fees because they cannot perform the calculus. 
In addition, a sophisticated plaintiff who could not deduct attorneys' fees pursuant to $\$ 212(1)$ of the Code could hire an attorney in a state with a charging attorney's lien like that in Alabama, not pay his attorney until he wins a judgment, and then exclude his income. ${ }^{172}$ Hopefully, courts would recognize this behavior as obvious tax evasion, but that should not be counted on. More importantly, the mere possibility of this behavior confirms the lack of guidance that state law provides in the exclusion analysis. Courts, therefore, should not rely on such an ambiguous theory of analysis to determine the rights of attorneys in contingent fee situations."

\section{State of Confusion: No Reconciliation of State Law and the Assignment of Income Doctrine}

The case law demonstrates that courts have yet to explain the relationship of the attorney's lien vis-à-vis the assignment of income doctrine; that is, it is unclear which is the threshold analysis. The Fifth Circuit had an opportunity to offer guidance in Srivastava because Texas law does not create as strong an attorney's lien as did the Alabama law in Cotnam. ${ }^{174} \mathrm{Had}$ it allowed exclusion solely on the basis of the joint venture argument, the Fifth Circuit would have established that the question of control of the legal claim was the threshold analysis. The Fifth Circuit, however, wrote explicitly that it was required to follow Cotnam despite the Texas-Alabama distinction. ${ }^{175}$ Yet, the court also indicated that it might disallow exclusion if the issue had been one of first impression. ${ }^{176}$ The question, unfortunately, remains unanswered as to whether the court would disallow exclusion because the plaintiff-taxpayer violated the assignment of income doctrine or because the language of the Texas statute does not establish a strong attorney's lien.

The Fifth Circuit's cloudy opinion in Srivastava may nonetheless have conveyed an important message. Perhaps the court permitted exclusion because it could not tolerate the arbitrary results of exclusion in Alabama and non-exclusion in Texas, especially with potentially large sums of federal income tax at stake. This sets up a workable solu-

172 It is true that the legal system tolerates some forum shopping; consider the forum shopping that occurred prior to Erie v Tompkins. See Erie, 304 US 64, 73-74 (1938), discussing Black \& White Taxicab Co v Brown \& Yellow Taxicab Co, 276 US 518 (1928).

173 One last consideration is the theoretical concern that, if state law controls the exclusion question, plaintiffs will shop for states in which to contract with attorneys. The recent surge of case law concerning exclusion of contingent fees clearly demonstrates that some plaintiffs are keen enough to understand the ramifications of excluding fees.

174 Srivastava, 220 F3d at 357-58; Cotnam, 263 F2d at 125.

175 Srivastava, $220 \mathrm{~F} 3 \mathrm{~d}$ at $357-58$.

176 Id at 357 ("Were we ruling on a tabula rasa, we might be inclined to include contingent fees in gross income."). 
tion: permit exclusion in all cases regardless of the state's attorney lien laws.

\section{EXCLUSION SHOULD BE PERMITTED}

To resolve the circuit split and create a uniform doctrine, courts should permit exclusion of contingent attorneys' fees from a plaintiff's gross income in all cases. First, the anticipatory assignment of income doctrine ${ }^{177}$ is court-made law that should recognize the realities that (a) a client cannot assign judgment or settlement proceeds that would not exist without the attorney and that the client will never receive as income; and (b) the contingent fee contract gives the attorney a stake in a judgment or settlement. ${ }^{178}$ Second, this solution disregards state property law, the application of which generates inconsistent results. ${ }^{179}$ Third, permitting exclusion by recognizing the attorney's ownership interest eliminates the balancing act that courts face involving the assignment of income doctrine and attorney's liens created by state law. ${ }^{180}$ Finally, this solution aids taxpayers such as the taxpayer in Alexander who saw a $\$ 5,000$ pre-tax gain become a $\$ 48,500$ after-tax loss because he could neither exclude nor deduct his attorneys' fees. ${ }^{181}$

\section{A. A Plaintiff Should Not Be Taxed on His Attorney's Interest}

Although a legal claim originates from a taxpayer-client, the claim has little value without the services of an attorney. In theory, a legal claim has value before an individual hires an attorney. Most plaintiffs, however, must hire attorneys to maximize their return on a legal claim. Even if the attorney takes 40 percent of judgment or settlement proceeds pursuant to a contingent fee contract, the 60 percent of the proceeds that the plaintiff receives is greater than the entire proceeds the plaintiff would have received had he chosen selfrepresentation. ${ }^{\text {is }}$ The plaintiff could not have assigned the 40 percent of the proceeds to his attorney because the 40 percent did not exist when the plaintiff hired the attorney. The 40 percent exists only in theory only after the plaintiff hires the attorney, and it becomes reality only at the moment of judgment or settlement.

This nature of the contingent fee arrangement can be distinguished from the cases instituting the assignment of income doctrine,

177 See Part I.B.

178 See Part III.A.

179 See Part III.B.

180 See Part III.C.

18172 F3d at 940 . See text accompanying notes $12-13$.

182 See text accompanying notes $99-103$ (discussing why an individual has a better chance of maximizing proceeds from a settlement or judgment when he hires an attorney). 
in which the value of the income fluctuated irrespective of the assignment. With the contingent fee arrangement, the expected value of judgment or settlement proceeds increases when an attorney is hired. It is only because of the attorney's efforts that he receives his proceeds. In Earl and Horst, the donees performed no service that affected the value of their income received. ${ }^{183}$ Once the moment of judgment or settlement has arrived, a contingent fee attorney gains a strong contractual right to a portion of the proceeds subject only to certain reasonableness determinations. ${ }^{184}$ In essence, the attorney has accepted a proprietary interest in the lawsuit, which he is permitted to do under Model Rule of Professional Conduct $1.8(\mathrm{j}){ }^{185}$ Since the assignment of income doctrine is court-made law, courts should utilize its malleability to correct the apparent inconsistencies among contingent fee taxation cases.

\section{B. Consistency}

This Comment's proposed solution eliminates reliance on the state law of attorney's liens and thereby eliminates the arguably inconsistent results offered by the current case law. Courts have no guidance in interpreting state law concerning attorney's liens; if legislative history exists, the courts have so far failed to cite it. The Alabama statute in Cotnam giving attorneys equal rights with their clients over judgments was enough for the Fifth Circuit to permit exclusion. ${ }^{18}$ In Srivastava, however, the court permitted exclusion even though the applicable Texas law did not function like Alabama's. ${ }^{188}$ To date, no standard has emerged for how courts should interpret state law dealing with attorney's liens. This situation is further compounded by the existence of liens derived from common law and statute. In many

183 This is not an argument that the contingent tee scenario is distinguishable from Earl and Horst because the contingent fee attorney provides services in exchange for a portion of judgment or settlement proceeds. The argument is that the plaintiff does not assign the proceeds received by the attorney because the attorney creates the income himself. If a plaintiff contracted with some other party (but not his attorney) to give 10 percent of the proceeds he received from a judgment or settlement in exchange for something of value, and the plaintiff excluded that 10 percent from his taxable gross income, that would violate the assignment of income doctrine; it would be an assignment of speculative income, but the actual existence of the income does not depend on the party with whom the plaintiff contracted. It would be the same as Mr. Earl assigning his speculative work wages to his wife or a person assigning stock of a company to another person.

184 For a discussion of courts' adherence to contingent fee contracts subject to reasonableness determinations, see text accompanying notes 105-12.

185 See Part III.A.3.

186 See Kenseth, 114 Tax Ct at 419 (Chabot dissenting) (stating that courts have a right and an obligation to correct errors made in evolution of assignment of income doctrine).

187263 F2d at 125.

188 See Part II.B.3. 
cases, state laws, such as the Alabama statute, can even be construed to permit exclusion of all legal fees. Nevertheless, courts continue to turn to state law to answer the contingent fee exclusion question. Srivastava shows that circuit courts will be reluctant to permit differing applications of federal income tax law based on arcane and highly ambiguous interpretations of state law. ${ }^{189}$

The proposed solution also removes the balancing act that courts have not resolved involving the role of attorney's liens and the assignment of income doctrine. So long as courts feel compelled to examine state laws concerning attorney's liens, their analyses probably cannot be reconciled. Courts will continue to issue opinions such as Srivastava ${ }^{190}$ and Clarks, ${ }^{191}$ in which the courts reach their desired endpermitting exclusion-but brush over the laws regarding attorney's liens without explaining the laws' significance for the holding. ${ }^{192}$ Permitting exclusion by recognizing the ownership stake an attorney has in a contingent fee case would create a single, cogent doctrine.

\section{Permitting Exclusion Is an Equitable Result}

Although this Comment's solution is not based on fairness, it does address outcomes that may be perceived as inequitable. ${ }^{193}$ Individuals should not be discouraged from initiating meritorious lawsuits because of taxation of attorneys' fees. ${ }^{194}$ Regardless of fee-shifting provisions, ${ }^{195}$ the lawsuits most likely to be discouraged are those involving civil rights and employment discrimination. ${ }^{196}$ Intuition says that tax law should not stifle the advancement of civil rights and equity in the workplace. It is true that Congress could add deductions to handle these situations, but courts can correct the problem more rapidly through exclusion.

189 If one were convinced that state law must determine property rights for purposes of the exclusion question, the confusion created by the case law should at least lead to a rule of interpretation that absent a clear, unequivocal statement otherwise, attorneys' fees should be excluded.

$190220 \mathrm{~F} 3 \mathrm{~d}$ at 353.

191202 F3d at 854.

192 It should be noted that the Sixth Circuit's ruling in Clarks may have been driven by the court's preference for the "joint venture" rationale, while the Fifth Circuit decision in Srivastava was less favorable toward exclusion but was likely driven by a desire to avoid an intracircuit split based on highly ambiguous distinctions in state law.

193 See, for example, Alexander, 72 F3d at 940 (transforming plaintiff's $\$ 5,000$ pre-tax gain into a $\$ 48,900$ after-tax loss because of deduction limitations).

194 One counterargument is the following: if one accepts that attorneys will charge a higher percentage because they are no longer taxed on that percentage, exclusion will bring about a transfer from the government to attorneys rather than to plaintiffs.

195 See note 5 for a discussion of Venegas and fee shifting.

196 See Sager and Cohen, 73 S Cal L Rev at 1100 (cited in note 13). 


\section{Contingent Fee Arrangements Should Not Be Discouraged}

The greatest criticism of this solution might be that it encourages contingent fee agreements. One major concern with contingent fees is that experienced attorneys can use their superior knowledge of the costs and risks of litigation to set a bloated percentage fee that does not correlate to the actual time and risk employed by the lawyer. ${ }^{197}$ In addition, when an attorney is not paid by the hour, he might be quicker to convince his client to cease litigation prematurely."

The contingent fee contract, however, exists because of several benefits that outweigh any negatives. The possibility of a contingent fee arrangement could help convince a risk-averse person with a meritorious claim to file a lawsuit. In addition, contingent fees shift more risk to the attorney, who provides services for which he does not know if he will be compensated. An attorney might work harder or give his best effort if his compensation depends on that particular effort. ${ }^{199} \mathrm{Fi}$ nally, if concerns remain regarding the potential for bloated contingent fees, courts' imposition of reasonableness on fees ${ }^{200}$ and the Model Rules' prohibition on unreasonable fees ${ }^{201}$ ease these worries at least in part.

\section{CONCLUSION}

The contingent fee arrangement is unique. An individual can only increase the value of his legal claim by entering into an agreement giving his attorney the right to a share of any judgment or settlement proceeds-proceeds that would not exist without the attorney's effort. If there is no judgment or settlement, the attorney gets nothing. As the ABA's Model Rules recognize, ${ }^{202}$ the attorney owns a portion of the claim; the client and his attorney are partners in a joint venture. Because of this relationship, the client should not include the attorney's share of a judgment or settlement as part of the client's gross income. The client has hired the attorney to access the value of the client's

197 See Wolfram, Modern Legal Ethics at 529 (cited in note 61).

198 Id. See also. Murray L. Schwartz and Daniel J.B. Mitchell, An Economic Analysis of the Contingent Fee in Personal-Injury Litigation, 22 Stan L Rev 1125, 1126-27 (1970) (explaining that attorneys' interests and clients' interests may not necessarily be aligned in contingent fee arrangements).

199 See Rossi, 1 Attorneys' Fees at 96 (cited in note 169) ("[P]roponents of the contingent fee arrangement contend that it permits an attorney to devote his full time and attention to a case."). But see Richard W. Painter, Litigating on a Contingency: A Monopoly of Champions or a Market on Champerty?, 71 Chi Kent L Rev 625, 670-74 (1995) (explaining how contingent fee arrangements may cause attorneys to pursue litigation and settlement strategies that do not maximize client welfare).

200 See text accompanying notes 105-12.

201 See Model Rule of Professional Conduct 1.5.

202 See text accompanying notes $121-25$. 
share of the legal claim. The attorney necessarily has his own share of the legal claim because the attorney is a requisite part of the lawsuit. Although some courts view the contingent fee arrangement as a violation of the assignment of income doctrine, the doctrine should not apply because the client never assigned income. The client should not include the attorney's share in his gross income. 